\title{
Patchiness of epibenthic megafauna on the outer Grand Banks of Newfoundland
}

\author{
David C. Schneider ${ }^{1}$, Jean-Marc Gagnon ${ }^{2}$, Kent D. Gilkinson ${ }^{3}$ \\ ' Newioundland Institute for Cold Ocean Science, Memorial University of Newfoundland, St. John's, Newfoundland A1B 3X7, \\ Canada \\ 2 Department of Biology, Memorial University of Newfoundland, St. John's, Newioundland A1B 3X9, Canada \\ ${ }^{3}$ Fudge, Lane, and Associates Limited, PO Box 9370. Station B, 607 Torbay Road, St. John's, Newfoundland A1A 2 X3, Canada
}

\begin{abstract}
Photographic transects were used to investigate the distribution of megafauna in relation to substrate variability on the outer Grand Banks. Sedimentary cover consisted of reworked glacial deposits arranged in alternating bands of gravel and sand. Megafaunal density was higher along transects with elevational gradients of $1 \mathrm{~m} \mathrm{~km}^{-1}$ than along transects with less gradient. Sessile, discretely motile, crawling, and swimming animals were spatially autocorrelated as indicated by significant increase in variability with increase in length scale. Cross-correlation with substrate was stronger at large $(>100 \mathrm{~m})$ than at smaller spatial scales in sessile, discretely motile, crawling, and swimming animals. Local decoupling from substrate features was observed in swimming animals. Our results were consistent with the hypothesis that mobility determines the spatial scales over which the densities of benthic organisms are associated with substrate variability.
\end{abstract}

\section{INTRODUCTION}

Sheets of actively reworked sand are ubiquitous features of continental shelves (Nittrouer 1981, Stride 1982). Bedforms range in scale from ripples on the order of a metre or less, to sand ribbons on the order of hundreds of metres, and sand waves on the order of thousands of metres. Recent work in the English Channel has shown that epibenthic megafauna are associated with large-scale habitat features such as sand ribbons (Holme \& Wilson 1985), but this has not been investigated quantitatively.

We investigated the distribution of megafauna relative to small- and large-scale variation in substrate along 5 photographic transects across the northeast edge of the Grand Banks, in the northwest Atlantic (Fig. 1). The hydrographic regime of outer Grand Banks is strongly influenced by the Labrador Current, which carries cold water of reduced salinity (28 to $30 \mathrm{ppt}$ ) along the shelf break. Important physical forces include tidal mixing near the bottom, and vigorous stirring of the water column by seasonal storms with wind velocities that exceed $140 \mathrm{~km} \mathrm{~h}^{-1}$ (Mobil 1985). Maximum reported tidal currents on the outer Grand Banks are $15 \mathrm{~cm} \mathrm{~s}^{-1}$ at $80 \mathrm{~m}$ depths (Mobil 1985). Further description of the hydrographic regime can be found in Mobil (1985) and Petrie \& Anderson (1983).

Sedimentary cover on the Grand Banks typically consists of reworked sand and gravel deposits (Fader \& King 1981). Bedforms include ripples on the order of a metre or less, megaripples on the order of $5 \mathrm{~m}$, sand ribbons on the order of $100 \mathrm{~m}$ in width, and large sand fields in excess of $400 \mathrm{~m}$ in width (Barrie et al. 1984). Reworking of the sediment is evident after seasonal storms (Barrie et al. 1984).

Benthic organisms found in the outer Grand Banks have been listed by Allen (1965), Nesis (1965), Pitt (1973, 1976), Steele et al. (1979), Hutcheson et al. (1981), and Houston \& Haedrich (1984). The density, patchiness, and substrate preferences of benthic megafauna have not been reported. The objectives of our study were (1) to quantify megafaunal patchiness over a range of spatial scales; (2) to determine whether megafauna were locally correlated with the presence of sand, gravel, shell, or cobble; and (3) to determine whether megafauna were correlated with larger scale substrate features such as sand ribbons. Megafauna differ in their mobility and our expectations were that the abundance of mobile animals would be more highly correlated with large-scale than with local variation in substrate. Jumars (1976) hypothesized that the abundance of animals with little or no mobility would 


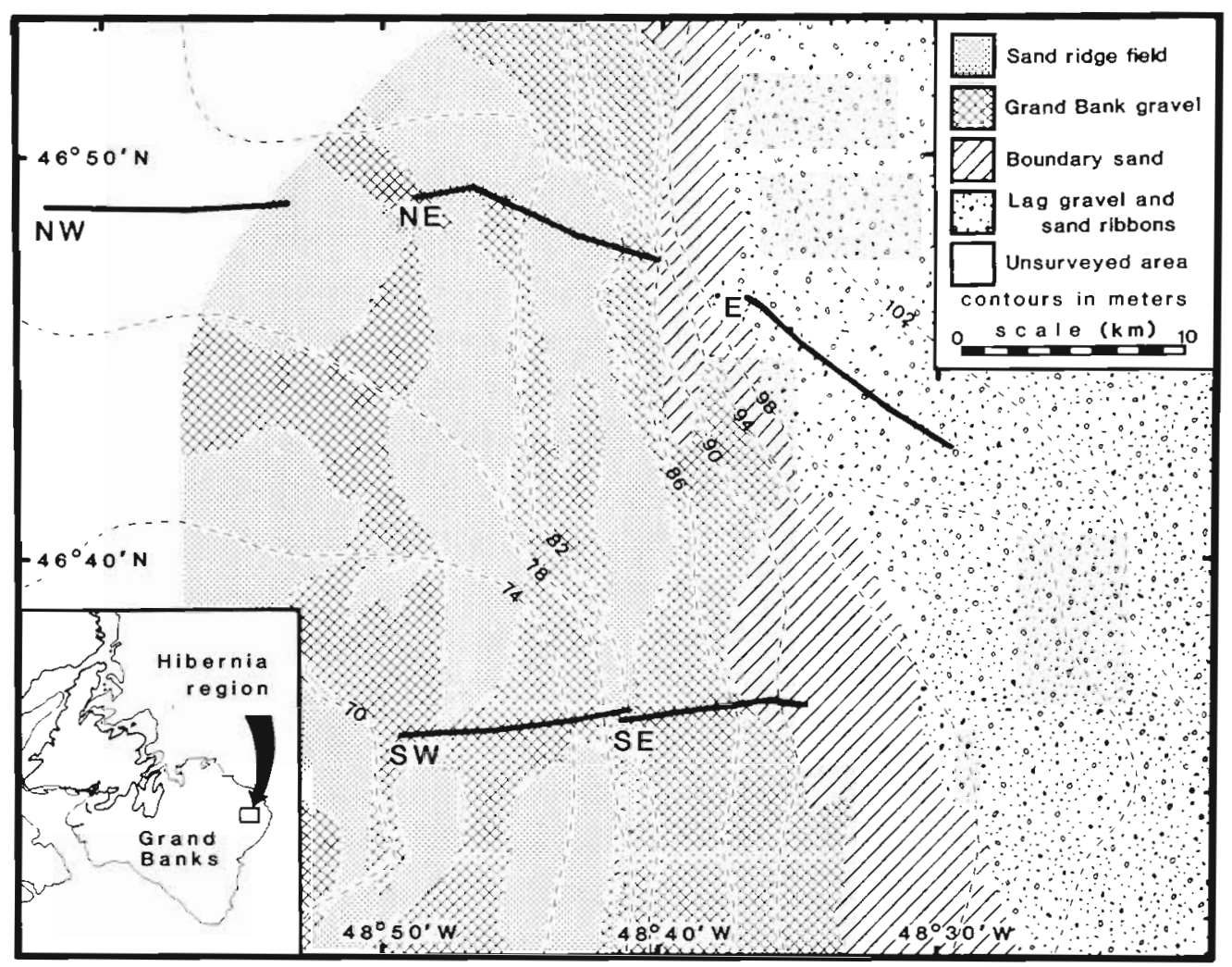

Fig. 1 Location of benthic transects on northeastern edge of the Grand Banks, in the northwestern Atlantic. Depth contours in metres

be correlated with local variation in the environment. In formal terms, the differential mobility model of habitat association was:

and

$$
\mathrm{d} \rho_{\mathrm{m}} / \mathrm{dL}>0
$$

$$
\rho_{\mathrm{m}}<\rho_{\mathrm{s}} \text { when } \mathrm{L}=\mathrm{S}
$$

where $\rho_{m}=$ the correlation of mobile anımals with substrate; $\rho_{\mathrm{s}}=$ the correlation of sessile animals with substrate; $\mathrm{L}=$ = length scale; and $\mathrm{S}=$ minimum measurement distance.

To measure patchiness as a function of length scale we used the contiguous grouping technique of GreigSmith (1952), as modified by Kershaw (1957) Patchiness was measured by the variance-to-mean ratio because it allows comparison with previous benthic studies and because it is computationally equivalent to the statistic (mean squared deviation among groups) used by Greig-Smith (1952). The relation of patchiness to length scale is determined by computing this statıstic for successively larger blocks of contiguous quadrats. The statistic increases rapidly at length scales equal to patch size (Greig-Smith 1952). The statistic is independent of length scale in the absence of patchiness at scales greater than the minimum quadrat size. Rupley (1978) gives a mathematıcal analysıs of the method.

\section{METHODS}

Three photographic transects were completed on 4 Nov 1983; 2 more transects were completed the following day (Fig. 1). Colour photographs were taken at $10 \mathrm{~s}$ intervals with the BRUTIV system (Vilks 1984), which consists of a sled-mounted camera (aligned vertically) towed $3 \mathrm{~m}$ above the bottom. Distance above the bottom was maintained to within a foot $(30 \mathrm{~cm})$. The longitudinal acceptance angle (the arc between the lines running from the center of the lens to the sides of the picture in the direction of travel) was $49.8^{\circ}$ in water The lateral acceptance angle was $39.4^{\circ}$. The potential area visible in each photograph was $5.98 \mathrm{~m}^{2}$ Loss of image along the periphery of each photograph reduced this to $5.44 \mathrm{~m}^{2}$.

Each $35 \mathrm{~mm}$ photograph was examined under a dissectung microscope at magnifications of 6 and 16 diameters. The substrate in each photograph was classified into 1 of 6 categories: 1 , sand; 2, sand with scattered cobble; 3 , scattered gravel on sand; 4 , sand with cobble and shell; 5,50 to $80 \%$ cobble and gravel; $6,>80 \%$ cobble and gravel. Sand, gravel, and cobble were distingushed by textural differences in the photographs. Cobble distinguished by textural differences was found by durect measurement to be $1 \mathrm{~cm}$ or greater. These categones are a ranking of substrate rough- 
ness, which affects the flow field near the seafloor (Nowell \& Jumars 1984). Ripples were graded as present or absent.

Megafauna were operationally defined as any organism large enough to be identified in a photograph. Animals less than $2 \mathrm{~cm}$ in diameter were visible, but could not be identified. All megafauna were assigned to groups based on visible traits, primarily shape and colouration. Reference specimens and keys (Liem \& Scott 1966, Gosner 1971), were used to assign each group to the lowest possible taxonomic level. The protocol for interpreting photographs and identifying live animals is given in Appendix I.

Counts were made by superimposing a $5 \times 5$ grid over each slide, and recording the number of organisms in each cell. Analysis was carried out on the sum of the counts of each megafaunal group in each slide. Dead specimens were counted for comparison with the distribution of live animals; these results will be reported elsewhere.

Patchiness of megafauna was measured by computing a variance-to-mean ratio, I', over successively larger measurement intervals $F$. Computation of the statistic $I^{\prime}(F)$ was carried out over the range $1<F<T / 2$ where $T$ is the number of photographic frames per transect. Thus, $I^{\prime}(1)$ is the variance-to-mean ratio over all photographs within a transect, $I^{\prime}(2)$ is the varianceto-mean ratio over adjacent pairs of photographs, I'(3) is the variance-to-mean ratio over adjacent triplets of photographs, etc. Computations within each transect were restricted to integral values of $\mathrm{T} / \mathrm{F}$. Distance between successive photographs, $\mathrm{S}$, was computed from the formula:

$$
\mathrm{S}=\mathrm{t} v
$$

where $t=$ time between photographs; $v=$ ship speed. The distance between photographs varied among transects. To compare transects that differed in minimum distance, $\mathrm{S}$, we used the variance-to-mean ratio indexed by distance, $\mathrm{I}^{\prime}(\mathrm{L})$, which was obtained from the relation $\mathrm{L}=\mathrm{S} F$.

Association of megafauna with each of the 6 substrate categories was measured by computing the Pearson product-moment correlation coefficient, r. Correlations indexed by distance, $r(L)$, were computed for the same measurement distances as variance-to-mean ratios, I'(L).

Statistical significance was evaluated by randomization tests. Change in variability with change in measurement distance was tested for significance by comparing observed values of $I^{\prime}(L)$ to the distribution of values obtained by random permutations of the single frame counts, $N_{j}$. A Fortran subroutine (GGPER) from the International Mathematics and Statistics Library (IMSL 1982) was used to obtain random permutations of the location index ( $\mathrm{j}$ ) and these were used to reassign each single frame count to a new location along the transect. Each call to this subroutine generates a new seed, which we used in the next call to avoid identical permutations. The first null hypothesis, scale-independent variability,

$$
\mathrm{H}_{0}: \mathrm{I}^{\prime}(\mathrm{S})=\mathrm{I}^{\prime}(\mathrm{L})
$$

was rejected in favour of the alternative hypothesis

$$
\mathrm{H}_{\mathrm{A}}: \mathrm{I}^{\prime}(\mathrm{S})<\mathrm{I}^{\prime}(\mathrm{L})
$$

if an observed value of $\mathrm{I}^{\prime}(\mathrm{L})$ exceeded 95 out of 100 values of $I^{\prime}(L)$ obtained by randomizing the single frame counts, $\mathrm{N}_{\mathrm{J}}$.

Local correlation with substrate was tested for significance by comparing the observed value of $r(S)$ to 100 values of $r(S)$ obtained from 100 randomizations of the single frame counts, $N_{j}$. Substrate was not randomized in this analysis. The second null hypothesis, no local correlation

$$
\mathrm{H}_{0}: \mathrm{r}(\mathrm{S})=0
$$

was rejected if an observed value of $\mathrm{r}(\mathrm{S})$ was greater than 95 out of 100 values of $r(S)$ from randomized data.

The third null hypothesis, scale-independent correlation,

$$
\mathrm{H}_{0}: \mathrm{r}(\mathrm{S})=\mathrm{r}(\mathrm{L})
$$

was rejected in favor of the alternative hypothesis

$$
\mathrm{H}_{\mathrm{A}}: \mathrm{r}(\mathrm{S})<\mathrm{r}(\mathrm{L})
$$

if an observed value of $r(L)$ was greater than 95 out of 100 values obtained from randomized data.

\section{RESULTS}

Live megafauna were categorized into 24 groups (Table 1). Polytypic groups were Porifera, Hydrozoa and Bryozoa, Buccinidae, Majidae, Holothuroidea, and unidentified ophiuroids. Remaining groups were monotypic, based on traits visible in photographs. Echinodermata were the most frequently encountered phylum along the transects (Table 1). The next most abundant phyla were Mollusca, Annelida, Chordata (fish), and Cnidaria. The 4 most abundant groups ( 3 echinoderms and 1 mollusc) accounted for $89 \%$ of all live megafauna seen along the transects. Crustaceans accounted for $3 \%$ of all animals seen, fish accounted for $1 \%$.

Each group was assigned to 1 of 4 locomotory categories: sessile, discretely motile, crawling, or swimming (Table 1). Crawling animals were the most abundant category, accounting for $72 \%$ of all animals seen. The next most abundant category was discretely motile animals (24\%), followed by sessile (3\%), and 
Table 1 . Counts of visible megafauna along 5 benthic transects with a combined length of $48.8 \mathrm{~km}$, and a total area of 1.9 ha. Mobility categories based on general knowledge: $m$, discretely motile; n, swimming; r, crawling; s, sessile. Feeding classification from Nesis (1965): f, sestonophage; g, gatherer of detritus; $i$, ingestor of bottom sediment; $p$, predatory, scavenging, and omnivorous

\begin{tabular}{|c|c|c|c|}
\hline Taxon & Counts & Mobility & Feeding \\
\hline A Porifera & 23 & $s$ & $f$ \\
\hline B Hydrozoa and Bryozoa & 260 & $s$ & $\mathrm{f}$ \\
\hline C Actinidae (Cnidaria) & 240 & $\mathrm{~s}$ & $\mathrm{p}$ \\
\hline D Sabellidae (Annelida) & 348 & s & $\mathrm{f}$ \\
\hline \multicolumn{4}{|l|}{ Mollusca } \\
\hline E Buccinidae & 841 & r & $\mathrm{p}$ \\
\hline G Chlamys islandica & 6969 & $m$ & f \\
\hline \multicolumn{4}{|l|}{ Crustacea } \\
\hline H Majidae & 751 & $\mathrm{r}$ & $\mathrm{p}$ \\
\hline I Pagurus spp. & 62 & $\mathrm{r}$ & $\mathrm{p}$ \\
\hline \multicolumn{4}{|l|}{ Echinodermata } \\
\hline J Holothuroidea & 11 & $\mathrm{r}$ & $\mathrm{f}$ \\
\hline K Strongylocentrotus pallidus & 5110 & $\mathrm{r}$ & $\mathrm{p}$ \\
\hline L Echinarachnius parma & 7430 & $\mathrm{r}$ & $\mathrm{f}$ \\
\hline N Solasteridae & 24 & $\mathrm{r}$ & $\mathrm{p}$ \\
\hline O Henricia & 10 & $\mathrm{r}$ & $\mathrm{f}$ \\
\hline $\mathrm{P}$ Asterias & 35 & r & $\mathrm{p}$ \\
\hline Q Leptasterias & 183 & r & $\mathrm{p}$ \\
\hline R Unid asteroids & 48 & $r$ & $\mathrm{p}$ \\
\hline S Gorgonocephalus sp. & 280 & $\mathrm{~m}$ & $\mathrm{p}$ \\
\hline T Unid. ophiuroidea & 7615 & $\mathrm{r}$ & g \\
\hline \multicolumn{4}{|l|}{ Chordata } \\
\hline U Rajidae & 43 & n & $\mathrm{p}$ \\
\hline V Gadidae & 65 & $\mathrm{n}$ & $\mathrm{p}$ \\
\hline W Ammodytes spp. & 84 & $\mathrm{n}$ & $\mathrm{p}$ \\
\hline X Zoarcidae & 7 & $\mathrm{n}$ & $\mathrm{p}$ \\
\hline Y Cottidae & 7 & $\mathrm{n}$ & $\mathrm{p}$ \\
\hline Z Pleuronectidae & 144 & n & $\mathrm{p}$ \\
\hline
\end{tabular}

swimming (1\%) animals. Each group was also categorized according to the feeding classes used by Nesis (1965). Three feeding classes were observed: sestonophages ( $49 \%$ ), gatherers of detritus $(25 \%)$, and predatory and omnivorous forms (26\%). Sestonophages include filter and suspension feeders.

The coarse scale $(>1 \mathrm{~km})$ structure of the habitat was

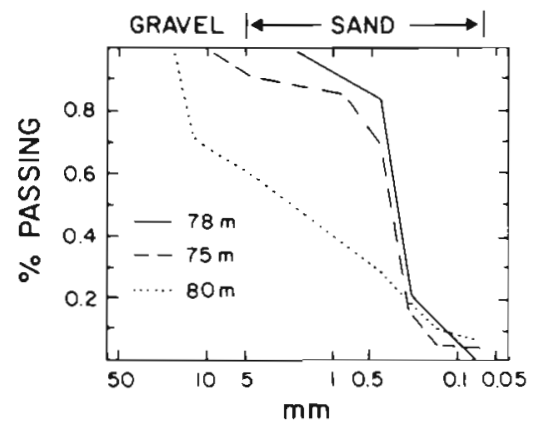

Fig. 2. Cumulative frequency distribution of sediment from outer Grand Banks. Sample from $78 \mathrm{~m}$ collected at $46^{\circ} 46^{\prime} 02^{\prime \prime} \mathrm{N}, 48^{\circ} 45^{\prime} 52^{\prime \prime} \mathrm{W}$; sample from $75 \mathrm{~m}$ collected at $46^{\circ} 44^{\prime} 58^{\prime \prime} \mathrm{N}, 48^{\circ} 47^{\prime} 44^{\prime \prime} \mathrm{W}$; sample from $80 \mathrm{~m}$ collected at $46^{\circ} 44^{\prime} 48^{\prime \prime} \mathrm{N}, 48^{\circ} 49^{\prime} 38^{\prime \prime} \mathrm{W}$

described by Barrie et al. (1984) on the basis of sidescan sonar, seismic profiles of the substrate, and bottom photography. Fig. 1 shows the distribution of transects in relation to the coarse-scale features mapped by these authors. The northwest transect (NW in Fig. 1) ended in a sand ridge field. The northeast transect (NE) crossed 2 sand ridge fields, which typically lie unconformably over gravel and cobble (Barrie et al. 1984). The east transect $(E)$ crossed a gravel and cobble field with narrow sand ribbons. The southwest transect (SW) crossed a sand ridge field, a gravel and cobble field, and ended in a second sand ridge field. The southeast transect (SE) ended in boundary sand, which separates the sand field province in shallow water from the sand ribbon province in deeper water to the east (Fig. 1).

Fine sand $(<0.425 \mathrm{~mm})$ occurs outside (east) of the $100 \mathrm{~m}$ isobath, medium sand occurs between the $100 \mathrm{~m}$ and $80 \mathrm{~m}$ isobath, and coarse sand (>2 mm) occurs inside the $80 \mathrm{~m}$ isobath (Barrie et al. 1984). Sediment collected near the northeast transect consisted of fine to medium well-sorted sand, or sand mixed with gravel (Fig. 2). The samples from 78 and $75 \mathrm{~m}$ of water were collected in the sand ridge field south of the northeast transect. The sample from $80 \mathrm{~m}$ was collected from the gravel field near the beginning of the northeast transect.

Table 2. Counts of visible megafauna along 5 benthic transects on the northeastern edge of the Grand Banks. T: number of photographs

\begin{tabular}{|lccccc|}
\hline & Northwest & Northeast & East & Southwest & Southeast \\
\hline T (frames) & 720 & 750 & 750 & 720 & 576 \\
Length (km) & 10.1 & 10.2 & 9.7 & 10.0 & 0.39 \\
Area (ha) & 0.39 & 804 & 168 & 0.31 \\
Moliusca & 142 & 1977 & 1342 & 4129 & 2567 \\
Echinodermata & 789 & 95 & 31 & 15194 & 75 \\
Pisces & 93 & 888 & 549 & 27 \\
Other & 80 & & & 136 \\
\hline
\end{tabular}


The abundance of visible megafauna varied from transect to transect (Table 2) and was associated with bathymetric gradients shown in Fig. 1. Megafaunal density was relatively high on the SE, SW, and NE transects, which had changes in elevation of $1 \mathrm{~m} \mathrm{~km}^{-1}$ or more (Fig. 1). Densities were lower on the NW and E transects (Table 2), which had changes in elevation of less than $1 \mathrm{~m} \mathrm{~km}^{-1}$ (Fig. 1). Echinoderms and molluscs together were more abundant on the SE, SW, and NE transects than on the NW and E transects. The number of transects was too limited to test whether the observed relation between density and bathymetric gradient could be inferred for the area around the transects.

The fine scale $(10$ to $1000 \mathrm{~m})$ distribution of substrate categories is shown in Fig. 3 to 7. The northwest transect crossed a sand ridge field with areas of scattered cobble and scattered gravel (Fig. 3). The northeast transect intersected 2 sand ridge fields (Fig. 1) that were relatively free of cobble, gravel, or shell (Fig. 4). The east transect crossed a gravel and cobble field (Fig. 1) with narrow sand ribbons (Fig. 5). The southwest transect crossed a gravel and cobble field (Fig. 1) with a regular alternation of sand and cobble (Fig. 6). The southeast transect crossed a gravel and cobble field and intersected a sand field at its eastern end (Fig. 7).

Ripples, which indicate strong flow near the bottom,

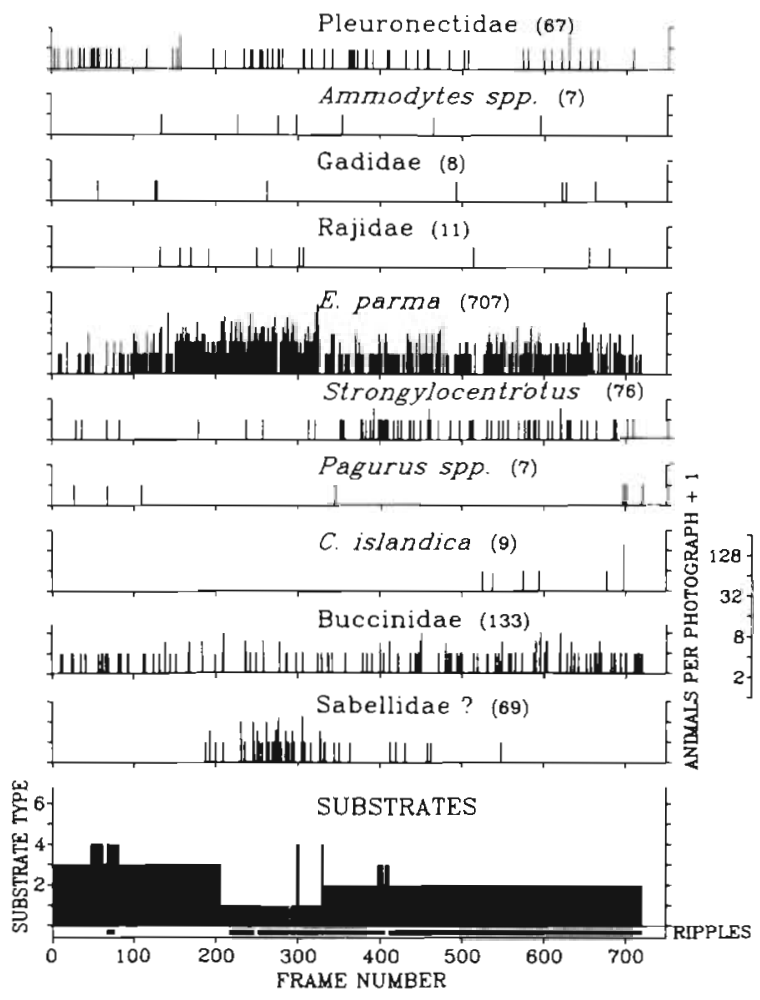

Fig. 3. Distribution of common taxa along the northwest transect on the outer Grand Banks. Common taxa are those with more than 5 individuals per transect

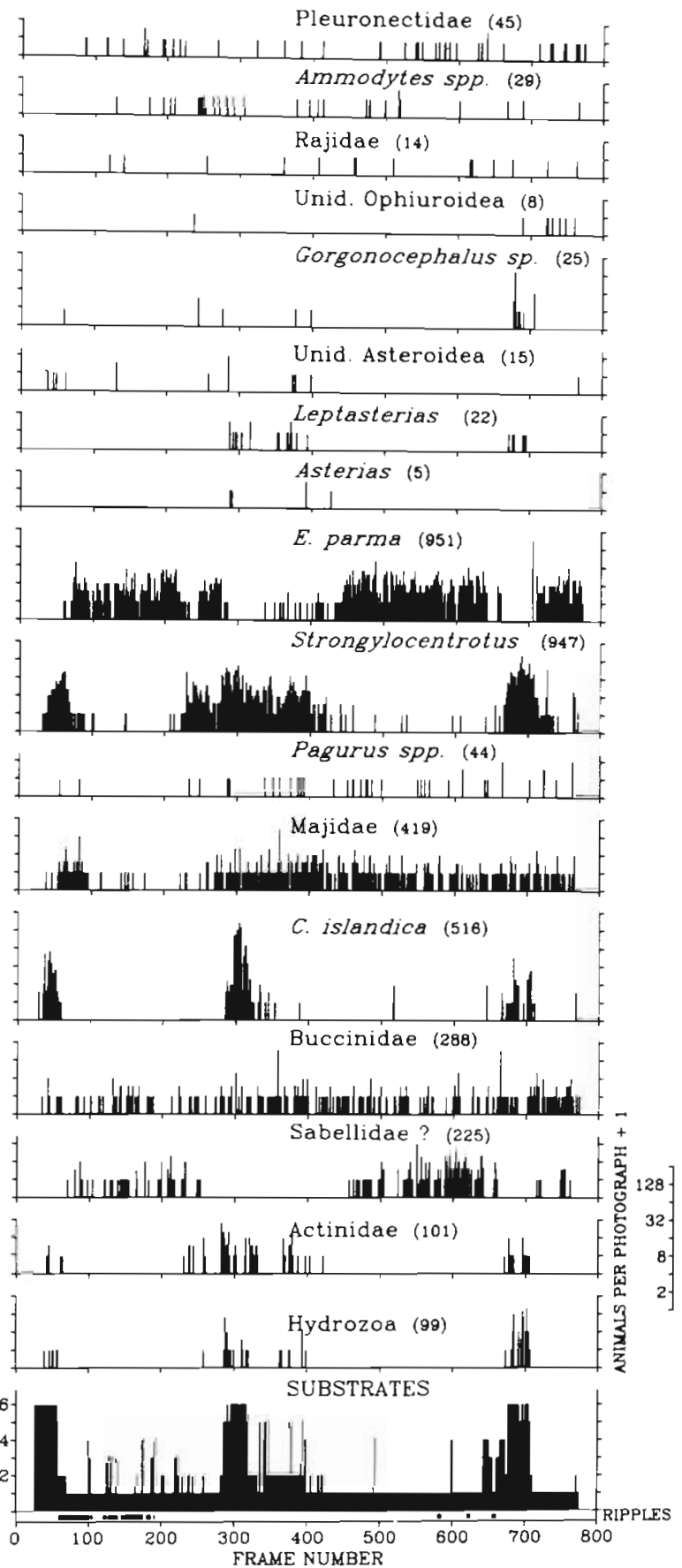

Fig. 4. Distribution of common taxa along the northeast transect on the outer Grand Banks

occurred along all but the southwest transect (Fig. 3 to 7). Substrate categories occurred in sequences rather than at random.

Sessile and discretely motile fauna were aggregated at the scale of a single photograph, as indicated by variance-to-mean ratios greater than unity. Out of 22 ratios computed for sessile and discretely motile groups, 19 were greater than unity (Table 3). Crawling 


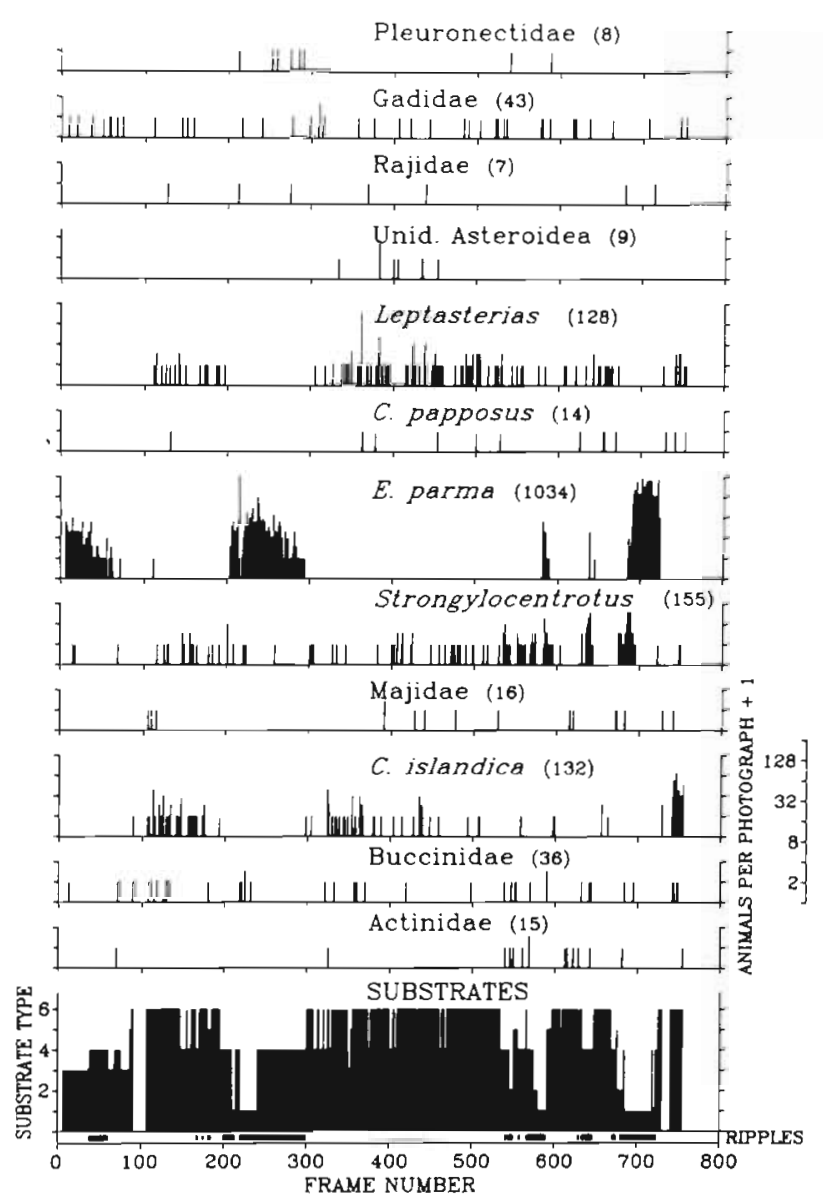

Fig. 5. Distribution of common taxa along the eastern transect on the outer Grand Banks

and swimming groups were less frequently aggregated at this scale. Out of 76 ratios computed for mobile groups, only 36 were greater than unity. Aggregation in all groups was scale-dependent, as indicated by significantly higher variance-to-mean ratios at larger measurement intervals than at the scale of a single photograph (Table 3). The increase in variability with increase in measurement interval results from spatial autocorrelation (Ripley 1978). Spatial autocorrelation is evident in Fig. 3 to 7 , which show that many groups tend to occur in aggregations extending over a series of photographs, rather than as point aggregations confined to a single photograph.

Local and larger scale responses to spatially autocorrelated habitat are potentially important sources of spatial autocorrelation in benthic animals. This was investigated by looking at local (single frame) and larger scale (multiple frame) correlations of megafauna with substrate. The sand dollar Echinarachnius parma was chosen for detailed presentation of results because it was abundant along all 5 transects (Fig. 3 to 7 ). The correlation of $E$. parma with fine sand, at the scale of a single photograph, ranged from +0.40 along the NW
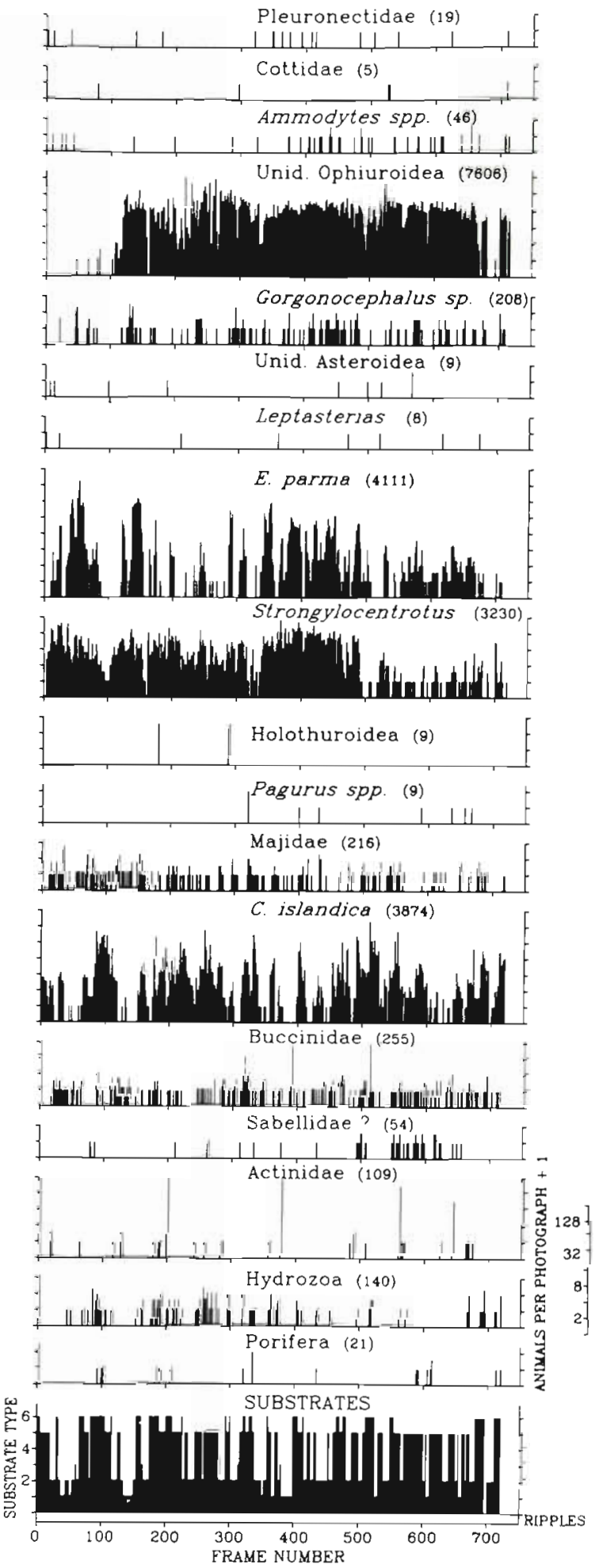

Fig. 6. Distribution of common taxa along the southwest transect on the outer Grand Banks

and NE transects to +0.71 along the E transect (Fig. 8). These correlations were significantly greater than zero (at $\mathrm{p}=0.05$ ), based on randomization tests.

Correlation of Echinarachnius parma with fine sand 


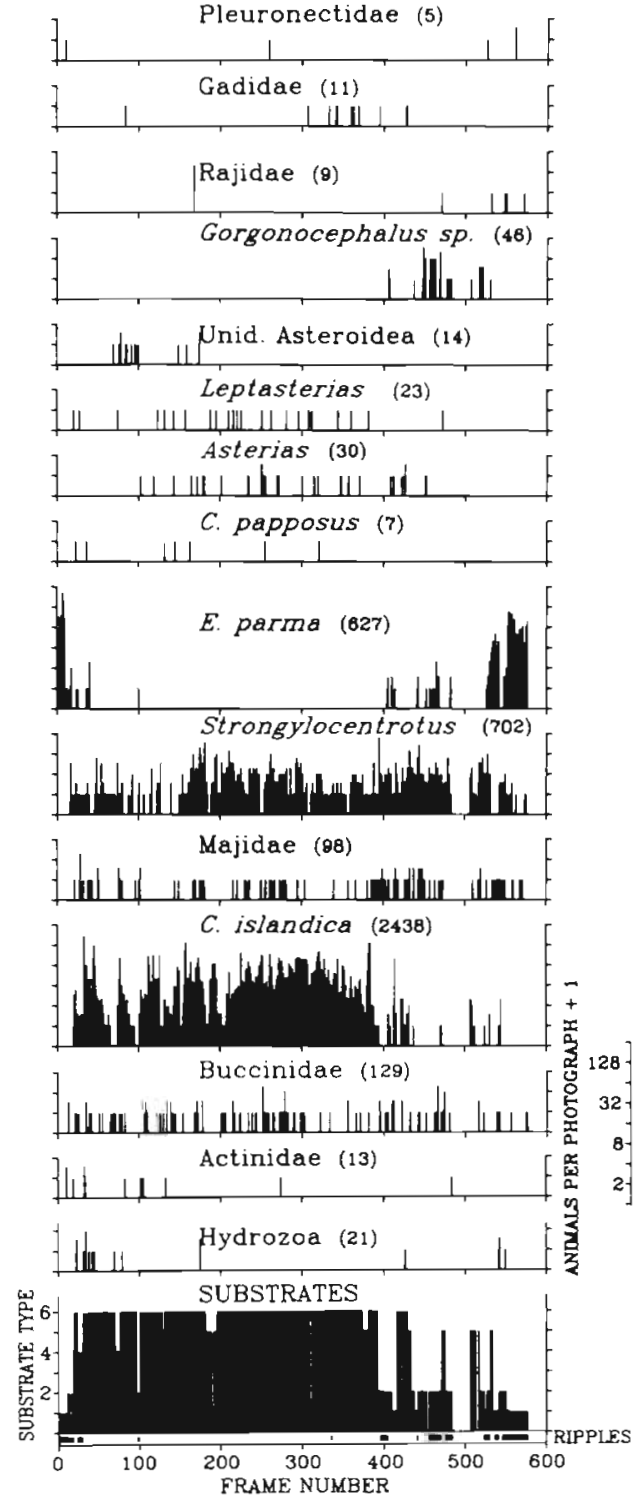

Fig. 7. Distribution of common taxa along the southeast transect on the outer Grand Banks

was significantly higher at larger measurement intervals than at the minimum interval of one photograph along the NE, NW, E, and SE transects (Fig. 8). Correlation did not increase significantly with measurement interval along the SW transect. The significance tests were based on randomizations of the data and hence do not depend on any assumptions about the underlying statistical distribution of the faunal data, the substrate data, or the correlation coefficient computed from untransformed data.

Correlation of Echinarachnius parma with fine sand increased steadily with increase in spatial scale but this was not observed in all groups. For example, the corre- lation of actinid anemones with cobble increased rapidly at length scales of 100 to $500 \mathrm{~m}$ (Fig. 9). Significant increase in correlation in other megafauna tended to occur at length scales on the order of 100 to $500 \mathrm{~m}$, rather than increasing steadily, as in E. parma (Fig. 8).

Correlation with substrate at the scale of a single photograph was stronger in sessile or crawling animals than in swimming animals (Fig. 10). Consistent preferences were observed in actinids, sabellids, scallops, and sand dollars. Clinging groups (Asteroidea, Gorgonocephalus, Strongylocentrotus pallidus) preferred cobble and avoided gravel and shell. Local correlation with ripples was positive in sabellids, Gorgonocephalus, S. pallidus, Echinarachnius parma, and pleuronectids (Fig. 10). Correlation with ripples was, in general, no stronger than the correlation with sand so there was no indication that animals preferred rippled sand. Positive correlation with ripples does show that these 5 groups tolerate strong flow over shifting substrates, either through resistance to strong flow and abrasion, or through ability to survive intermittent suspension. We note that Ursin (1960) has classifed Solaster papposus, Henricia sanguinolenta, Ophiura sarsi, Ophiura robusta, Cucumaria frondosa, and Strongylocentrotus as rheophilic.

Correlation with substrate was stronger over large distances than over short distances in swimming animals (Fig. 10). Only 7 significant local correlations were observed in swimming animals, compared to 16 significant correlations at a larger scale (Fig. 10). This ratio $(7: 16)$ differs significantly from the ratio $(56: 49)$ observed in less mobile animals $(\mathrm{G}=4.05, \mathrm{df}=1, \mathrm{p}=$ 0.04 ) based on a 2 by 2 contingency test (Sokal \& Rohlf 1981). Zoarcids showed a large-scale preference for gravel and shell, while flatfish showed a large-scale preference for sand and shell. Significant increase in correlation was also observed in sessile and crawling animals (Fig. 10).

\section{DISCUSSION}

Spatial structure due to autocorrelation has been reported in macrofaunal populations in deep-sea (Jumars \& Eckman 1983) and shallow-water habitats (Jumars et al. 1977). Variance-distance curves constructed by Grassle et al. (1975) suggest that deep-sea megafauna are autocorrelated, although this was not tested directly. We report significant autocorrelative spatial structure in continental shelf megafauna living on or just above the sea floor. Spatial autocorrelation, as indicated by a significant increase in variability with increase in length scale, was observed in sessile, discretely motile, crawling, and swimming megafauna on the outer Grand Banks. 
Table 3. Variability of common megafaunal animals visible along 5 benthic transects. Statistic is $\mathrm{I}^{\prime}$ (S), the variance-to-mean ratio at the minimum measurement distance $\mathrm{S}$. + indicates significant increase in the variance-to-mean ratio at larger measurement distances (see text)

\begin{tabular}{|c|c|c|c|c|c|}
\hline Taxon & Northwest & Northeast & East & Southwest & Southeast \\
\hline Porifera & & & & $1.3+$ & 1.0 \\
\hline Bryozoa and Hydrozoa & & $3.9+$ & & $1.7+$ & $1.5+$ \\
\hline Actinidae & 1.0 & $2.2+$ & $1.1+$ & 17.6 & $1.3+$ \\
\hline Sabellidae & $1.8+$ & $2.0+$ & & $1.3+$ & \\
\hline Buccinid A & 1.2 & $1.9+$ & $1.1+$ & $1.8+$ & $1.2+$ \\
\hline Buccinid B (Colus?) & & & & $1.3+$ & $1.7+$ \\
\hline Chlamys islandica & 2.3 & $15.4+$ & $2.5+$ & $14.1+$ & $9.5+$ \\
\hline Majidae & 1.0 & $1.5+$ & 1.1 & $1.4+$ & $1.2+$ \\
\hline Pagurus spp. & 0.99 & 1.4 & & 1.7 & 1.0 \\
\hline Holothuroidae & 1.0 & & & & 4.5 \\
\hline Strongylocentrotus pallidus & $1.0+$ & $4.7+$ & $1.9+$ & $5.9+$ & $2.6+$ \\
\hline Echinarachnius parma & $1.9+$ & $2.5+$ & $12.6+$ & $31.3+$ & $17.2+$ \\
\hline Solasteridae & & 1.0 & $0.98+$ & & 0.99 \\
\hline Henricia & 1.0 & 1.0 & & 1.0 & $0.99+$ \\
\hline Asterias & & 1.4 & & & $1.1+$ \\
\hline Leptasterias & 1.0 & $1.2+$ & $2.0+$ & 0.99 & 0.96 \\
\hline Unid. asteroidea & 1.0 & 1.5 & $1.7+$ & 1.2 & $1.3+$ \\
\hline Gorgonocephalus sp. & & $3.7+$ & 1.0 & $1.5+$ & $2.5+$ \\
\hline Unid. Ophiuroidea & & $0.99+$ & 1.0 & $8.8+$ & \\
\hline Rajidae & 0.99 & 0.98 & 0.99 & 1.0 & 2.3 \\
\hline Gadidae & 0.99 & 1.0 & 0.99 & & $0.98+$ \\
\hline Ammodytes spp. & 0.99 & $1.0+$ & 1.0 & $1.1+$ & 1.0 \\
\hline Zoarcidae & & 1.0 & 1.0 & 1.0 & 1.0 \\
\hline Cottidae & & 1.0 & & 0.99 & \\
\hline Pleuronectidae & $0.97+$ & 1.0 & $0.99+$ & $0.98+$ & 1.4 \\
\hline
\end{tabular}

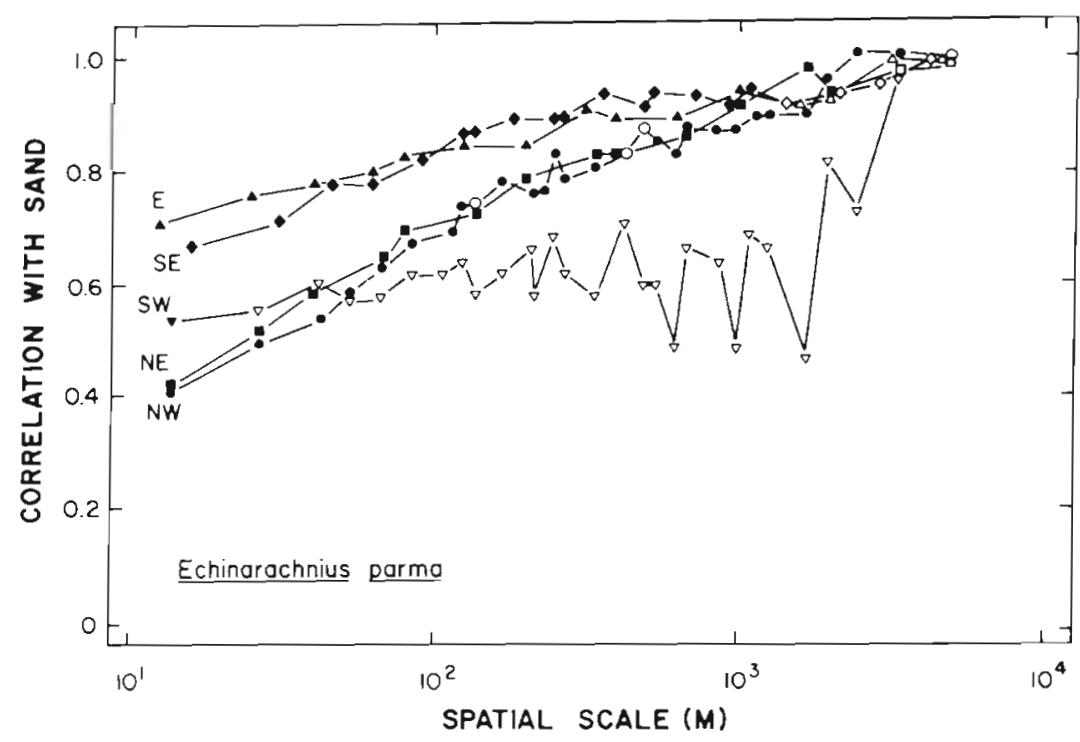

Fig. 8. Echinarachnius parma. Correlation with sand free of cobble and gravel. Solid symbols indicate significant correlation at $\mathrm{p}=0.05$ (see text). Open symbols indicate no significant correlation. SW: southwest transect, etc.
A variety of methods have been used to investigate spatial autocorrelation of marine organisms, including spectral analysis (Platt 1972, Platt \& Denman 1975), correlograms (Jumars et al. 1977), and variance-distance curves scaled to a Poisson process (Angel \& Angel 1967, Grassle et al. 1975). The equivalence of spectral analysis and variance-distance curves was demonstrated by Ripley (1978). The equivalence of spectral analysis and correlogram analysis, via a Fourier transform, has been noted in the marine literature by Mackas (1984). Variance-distance curves in the frequency domain are simple to construct and easy to 
Fig. 9. Correlation of Actinidae with cobble and gravel. Symbols as in Fig. 8
Fig. 10. Correlation of megabenthic animals with ripples (R) and with 6 categories of substrate. $r(S)$ is local correlation at scale of minimum sampling interval, which averaged between 13 and $14 \mathrm{~m} . \mathrm{r}(\mathrm{M})$ is larger scale correlation. See Table 1 for key to taxa
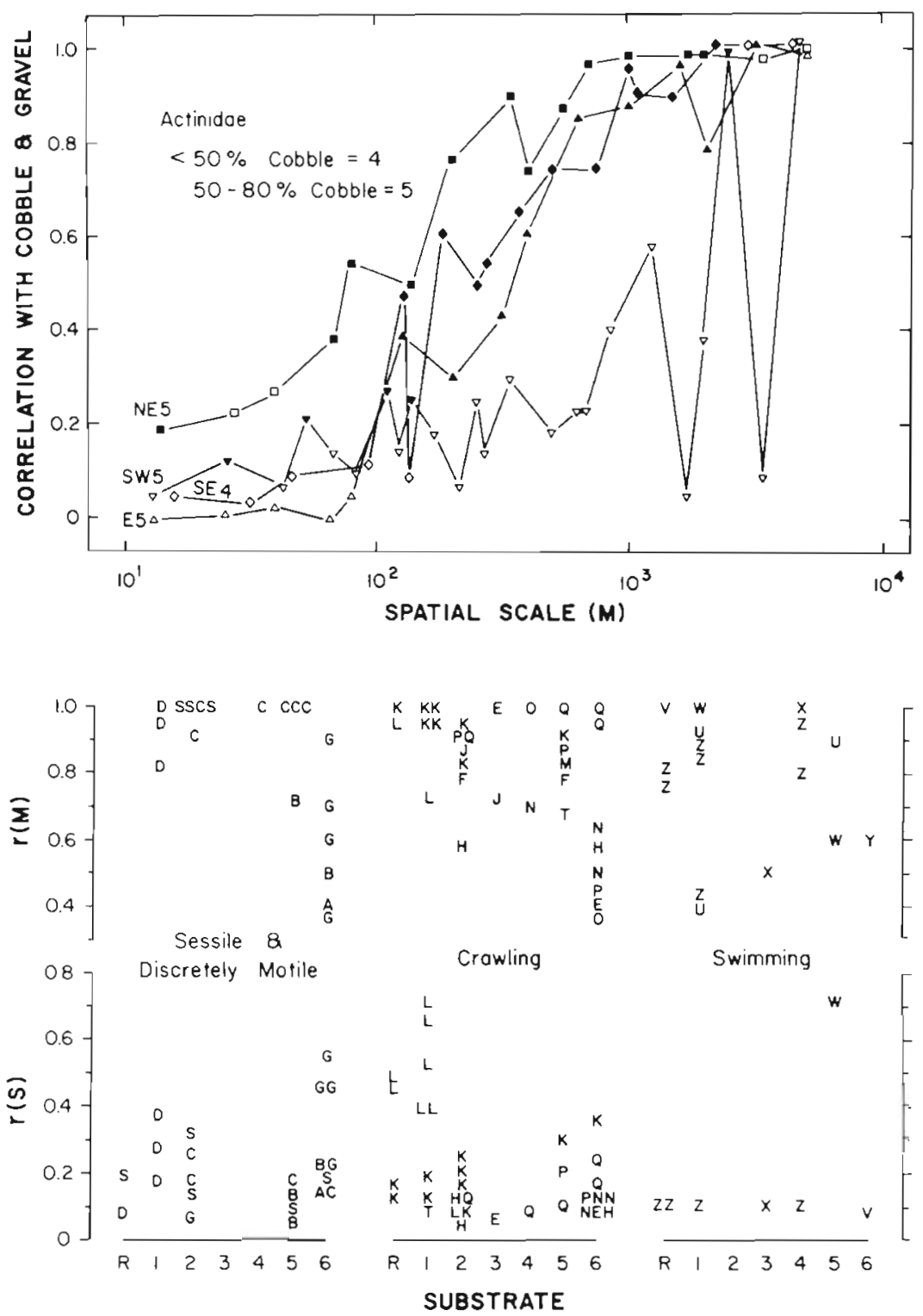

interpret (Greig-Smith 1964), but they are sensitive to choice of starting point. Reliability can be increased by a variety of smoothing techniques, including spectral analysis. Analysis in the distance domain is useful for irregularly placed samples, or when nearest neighbour distances are more easily measured than individual location. Distance and frequency specifications are interchangeable for point processes models (Cox \& Isham 1980). General treatments of spatial statistics can be found in Ripley (1981) and Upton \& Fingleton (1985).

Spatial variation in the abundance of benthic fauna has been analysed in the distance domain (Jumars et al. 1977. Jumars \& Eckman 1983) and in the frequency domain (Angel \& Angel 1967, Grassle et al. 1975). Analysis of benthic data has been restricted to the use of moment statistics, which provide averaged information and can at best describe only some aspects of spatial dependence. Moment-based statistics are useful in exploratory analysis, but they cannot be used in confirmatory analysis unless bias-reducing (Reed 1983) or bias-resistant techniques such as randomization tests (Hammersley \& Handscomb 1964) are used.

Spatial autocorrelation has important implications for the design of studies and the analysis of data (Matern 1960, Denman \& Mackas 1978). The presence of spatial autocorrelation in benthic megafauna means that statistical models based on additive effects ( $N$ = treatment + random effects) cannot be assumed in formal hypothesis testing, including the assessment of anthropogenic perturbation (Beanlands \& Duinker 1983). A more appropriate and sensitive procedure 
with spatially autocorrelated organisms such as benthic megafauna would be to test for change in spatial covariance with distance from the point or points of anthropogenic perturbation.

A variety of methods have been used to identify important habitat variables in marine environments. Eigenanalysis, including factor analysis and related multivariate methods, has been one of the most popular. Locally poor correlation with habitat features suggests that eigenanalysis may be more successful in identifying larger scale (>100 m) habitat variables than in identifying smaller scale variables. The effect of spatial autocorrelation on multivariate techniques such as eigenanalysis needs investigation.

Spatial autocorrelation also has implications for the identification of biotic interactions in benthic communities. Biological processes in the ocean may depend as much on spatial structure ('grain') as on total or average abundance. Examples of such processes include predation, which depends on the spatial structure of prey populations, and habitat selection, which depends on the spatial structure of the physical environment. The dependence of interaction on spatial structure can be demonstrated by defining the opportunity, $C$, for interaction between a population and an environmental factor as proportional to the product of local abundance $\sum_{\mathrm{i}=1}^{\mathrm{L}} \mathrm{N}_{\mathrm{i}}$ and local concentration of that factor $\sum_{1=1}^{\mathrm{L}} \mathrm{E}_{\mathrm{ij}}$ over the range $\mathrm{T}=\mathrm{n} \mathrm{L}$ :

$$
C=\frac{\sum_{j=1}^{\mathrm{n}}\left(\sum_{i=1}^{\mathrm{L}} N_{i j} \Sigma_{i=1}^{\mathrm{L}} \mathrm{E}_{1,}\right)}{\sum_{\mathrm{j}=1}^{\mathrm{n}} \sum_{i=1}^{\mathrm{L}} N_{\mathrm{ij}}}
$$

For any value of $\mathrm{L}$

$$
C(L)=\widetilde{N E} \bar{N}^{-1}+\bar{E}
$$

where $\widetilde{\mathrm{NE}}=$ the covariance of animal numbers with environmental factor $E_{;} \bar{N}=$ mean abundance per distance $L_{i}$ and $\bar{E}=$ mean concentration

If $\Sigma^{\mathrm{L}} \mathrm{E}_{1 \mathrm{j}}=\Sigma^{\mathrm{L}} \mathrm{N}_{\mathrm{ij}}-1$ (conspecifics within distance $\mathrm{L}$ )

$$
\text { then } C(\mathcal{L})=\tilde{N}^{2} \bar{N}^{-1}+\bar{N}-1
$$

which is Lloyd's (1967) measure of per capita contact rate with conspecifics over ambit $L$ (mean crowding).

Note that

$$
\overrightarrow{\mathrm{E}}=\mathrm{n}^{-1} \Sigma^{\mathrm{n}} \Sigma^{\mathrm{L}} \mathrm{E}_{\mathrm{ij}}=\mathrm{L} \mathrm{T}^{-1} \Sigma^{\mathrm{n}} \Sigma^{\mathrm{L}} \mathrm{E}_{\mathrm{ij}}
$$

and hence that $\mathrm{C}(\mathrm{L})$ scales as $\mathrm{L}^{+1}$ if covariation ( $\widetilde{\mathrm{NE}}$ ) or autocovariation $\left(\tilde{N}^{2}\right)$ scales as $L^{+1}$. We found that autocorrelation and covariation of epibenthic animals with substrate does not vary as $\mathrm{L}^{+1}$ and hence that opportunity for interaction cannot be scaled as $\mathrm{L}^{+1}$, as in standard Lotka-Volterra equations. We also found that the scaling of the substrate correlations with length was species-specific (compare Fig. 8 \& 9). Adequate theory and improved measurements of spatial autocorrelation in marine populations are needed to advance our understanding of contact-dependent processes such as predation, competition, and habitat selection.

Spatial autocorrelation can result from local processes, larger scale processes, or a combination of the two. Correlation with habitat features as a function of length scale has been reported in zooplankton (Mackas \& Boyd 1979, Star \& Mullin 1981) but has not been reported in benthic organisms. This can be traced to the difficulty of obtaining extensive data on habitat variables such as grain size, sediment chemistry, or water content of sediments (Rhoads 1970). We obtained extensive data on substrate roughness (sand, shell, gravel, \% cobble), an important index of habitat variation in an environment with strong flow regimes. Roughness categories were spatially autocorrelated along all transects and we found that faunal correlations with these categories were stronger over distances on the order of $100 \mathrm{~m}$ than over shorter distances.

Mobile predators in a spatially autocorrelated environment are likely to be found near important habitat features, but at any one time may not be found in local contact with any particular feature because of movement between patches. On the outer Grand Banks swimming megafauna were poorly correlated with local $(<15 \mathrm{~m})$ habitat variability, but were correlated with larger scale $(>100 \mathrm{~m})$ variability. Swimming megafauna were less frequently correlated with local variability than non-swimming megafauna. These results are consistent with the conjecture (Jumars 1976) that mobility results in local decoupling from structural features of the physical environment. We suspect that mobility determines the spatial scale at which benthic megafauna interact with prey and predators. We did not attempt an analysis of the spatial scale of preypredator interactions because little is known of the food habits of megafauna in our study area.

Our results indicate that large-scale processes (regional factors of MacArthur 1969 or long-distance factors of Matem 1960) need to be included in quantitative models of the distribution of epibenthic megafauna. One potentially important factor is the flow field near the sea floor (Warwick \& Uncles 1980, Nowell \& Jumars 1984). Scale-dependent deformation of the flow field near the sea floor may be a key factor for epibenthic megafauna because of the relation between flow, sediment mobility, and food supply to benthic animals (Sanders 1960).

Depth-dependent changes in feeding assemblages across boreal shelves have been described in the North Pacific (Zenkevitch 1963) and the North Atlantic (Nesis 1965). The predominance of sestonophages over detritus gatherers in grab samples at the edge of the 
Grand Banks (Nesis 1965) is consistent with our results for the animals observed in photographic transects. Depth-related changes in feeding modes and in biomass have been linked to depth-related changes in mixing regimes in the southeastern Bering Sea (Haflinger 1981). Optical survey techniques are a promising way of testing this linkage in boreal shelf ecosystems such as the Grand Banks.

The abundance of megafauna along the transects suggests that large animals may intercept a substantial amount of pelagically derived production on the outer Grand Banks each year. Biomass (Nesis 1965, Hutcheson et al. 1981, Houston \& Haedrich 1984) and respiratory requirements (Hutcheson et al. 1981) have been estimated for macrofauna taken in grab samples on the Grand Banks. Estimates of the biomass and respiratory requirements of megafauna will require spatially extensive surveys of the faunal abundance, which is autocorrelated over distances on the order of hundreds of metres.

Submersibles and remotely operated vehicles (ROVs) are promising equipment for obtaining extensive data on epibenthic and midwater organisms along experimental transects. Modern methods of line transect analysis (Burnham et al. 1980) will be needed to make full and effective use of this technology for investigating the structure and dynamics of animals living on and above the seafloor.

\section{APPENDIX I Interpretation of photographs}

All infaunal bivalve shells were classified as dead. This included Mya spp., Cyrtodaria siliqua, and all veneriids. Scallops Chlamys islandica, sand dollars Echinarachnius parma, sea urchins Strongylocentrotus spp., and gastropods (buccinids and naticids) were classified as live if they were in normal life position with normal colouration. Bleached specimens were classified as dead.

Stout, solitary anemones with rows of unbranched tentacles were classified as actinids. Stalked animals with base embedded in the sand, and with a radial arrangement of tentacles, were classified as sabellids. All live gastropods were classified as buccinids, based on shape and size. Young Apporhais occidentalis (Aporrhaidae) resemble buccinids in shape, but are too small to be visible in photographs. All identifiable scallops were ribbed, with unequal hinge ears, and were classified as Chlamys islandica. Spider crabs were classified as majids because none showed the spininess of Lithodes. The lack of tubercles and spines also eliminated Libinia. Hermit crabs were identified from protruding appendages and were almost certainly more abundant than indicated by our counts.

Holothuroidea were not classified to genus. Cucumaria frondosa is the mostly frequently encountered species on the outer Grand Banks (Nesis 1965); patches of Psolus sp. have also been observed in the study area (R. Hooper pers. comm.). All sea urchins were identified as Strongylocentrotus pallidus based on examination of 137 urchins collected from the northern Grand Banks in November 1986. Traits used for identification were those listed by Jensen (1974). All sand dollars were identified as Echinarachnius parma. Seastars with more than 9 arms were classified as Solasteridae. Most individuals appeared to be Crossaster papposus, based on their spiny appearance and the contrasting colour of the central disc. Whitish seastars with 5 slender arms were classified as Henricia. Seastars with 5 slightly stouter arms were classified as Asterias. Similarly shaped animals with 6 arms were classified as Leptasterias. Similarly shaped animals whose arms could not be counted were classified as unidentified asteroids. Ophiuroids with branched arms were classified as Gorgonocephalus. No attempt was made to classify other ophiuroids to lower taxonomic levels. Ophiura sarsi is the most abundant ophiuroid on the northeastern Grand Banks (Nesis 1965). O. robusta was the only ophiuroid found in grabs from the study area (Hutcheson et al. 1981). The latter species generally lives buried in the sediment. $O$. sarsi is larger and lives on the sediment surface (R. Hooper pers. comm.) and so probably accounted for most of the ophiuroids counted in photographic transects.

Skate-shaped fish were classified as rajids. The most common species taken in trawls on the Grand Banks is the thorny skate Raja radiata (Pinhorn 1976). Flatfish were classified as pleuronectids. The commonest species in bottom trawls in the study area is the American plaice Hippoglossoides platessoides (G. Lilly pers. comm.). Two cottids Triglops murrayi and Artediellus uncinatus were collected in sled samples from this area (Hutcheson et al. 1981).

Acknowledgements. We thank the Centre for Cold Ocean Research and Engineering (Memorial University of Newfoundland), the Atlantic Geosciences Centre (Bedford Institute of Oceanography, Dartmouth, Nova Scotia), the Offshore Geotechnics Program of the federal Panel on Energy Research and Development, T Folkes, M. Lewis, and the Captain and crew of the C.S.S. Hudson for logistic support. We thank Mobil Oil Canada, Ltd for permission to use sediment data, R. L. Haedrich for advice and comments, G. Lilly for specimens, and Computing Services at Memorial University for 2 megaseconds of free CPU time. We thank J. F. Grassle, R. Hooper, G. Lilly, W. Montevecchi, M. Segall, and R. Thompson for comments on the manuscript. This is NICOS Contribution No. 148 . 


\section{LITERATURE CITED}

Allen, J. A. (1965). Records of Mollusca from the Northwest Atlantic obtained by Canadian fishery research vessels, 1946-1961. J. Fish Res. Bd Can. 22: 977-997

Angel, H. H. Angel, M. V. (1967). Distribution pattern analysis in a marine benthic community. Helgoländer wiss. Meeresunters. 15: 445-454

Barrie, J. V., Lewis, C. F. M., Fader, G. B., King, L. H. (1984). Seabed processes on the northeastern Grand Banks of Newfoundland; modern reworking of relict sediments. Mar. Geol. 57: 209-227

Beanlands, G. E., Duinker, P. N. (1983). An ecological framework for environmental impact assessment in Canada. Dalhousie Univ. Institute for Resource and Environmental Studies, Halifax, Canada

Burnham, K. P., Anderson, D. R., Laake, J. F. (1980). Estimation of density from line transect sampling of biological populations. Wildl. Monogr. 72

Cox, D. R., Isham, V. (1980). Point processes. Chapman and Hall, London

Denman, K. L., Mackas, D. L. (1978). Collection and analysis of underway data and related physical measurements. In: Steele, J. H. (ed.) Spatial pattern in plankton communities. Plenum Press, New York, p. 85-109

Fader, G. B., King, L. H. (1981). A reconnaissance study of the surficial geology of the Grand Banks of Newfoundland. Current Res. Part A, Geol. Surv. Can., Ottawa, Pap. 81-1A: $45-81$

Gosner, K. L. (1971). Guide to identification of marine and estuarine invertebrates. John Wiley, New York

Grassle, J. F., Sanders, H. L., Hessler, R. R., Rowe, G. T., McLellan, $T$ (1975). Pattern and zonation: a study of the bathyal megafauna using the research submersible Alvin. Deep Sea Res. 22: 457-481

Greig-Smith, P. (1952). The use of random and contiguous quadrats in the study of the structure of plant communities. Ann. Bot. 16: 293-316

Greig-Smith, P. (1964). Data on pattern within plant communities. I. The analysis of pattern. J. Ecol. 49: 695-702

Haflinger, K. (1981). A survey of benthic infaunal communities of the southeastern Bering Sea shelf. In: Hood, D. W., Calder, J. A. (ed.) The eastern Bering Sea shelf: oceanography and resources. U. S. Dept. Commerce, Washington, D. C., p. 1091-1104

Hammersley, J. M., Handscomb, D. C. (1964). Monte Carlo methods. Methuen, London

Holme, N. A., Wilson, J. B. (1985). Faunas associated with longitudinal furrows and sand ribbons in a tide-swept area in the English Channel. J. mar. biol. Ass. U. K. 65: 1051-1072

Houston, K. A., Haedrich, R. L. (1984). Abundance and biomass of macrobenthos in the vicinity of Carson Submarine Canyon, northwest Atlantic Ocean. Mar. Biol. 82: 301-305

Hutcheson, M. S., Stewart, P. L., Spry, J. M. (1981). The biology of benthic communities of the Grand Banks of Newfoundland. MacLaren Plansearch report to Mobil Oil Canada Ltd, St. John's

IMSL (1982). International Mathematics and Statistics Library, Houston, Texas

Jensen, M. (1974). The Strongylocentrotidae (Echinoidea), a morphologic and systematic study. Sarsia 57: 113-148

Jumars, P. A. $(1976)$. Deep-sea species diversity: does it have a characteristic scale? J. mar Res. 34: 217-246

Jumars, P. A., Eckman, J. E. (1983). Spatial structure within deep-sea benthic communities. In: Rowe, G. T. (ed.) The sea, Vol. 8. Biology of the deep-sea. Wiley-Interscience, New York, p. $399-452$

Jumars, P. A., Thistle, D., Jones, M. L. (1977). Detecting twodimensional spatial structure in biological data. Oecologia (Berl.) 28: 109-123

Kershaw, K. A. (1957). The use of cover and frequency in the detection of pattem in plant communities. Ecology 38: 291-299

Liem, A. H., Scott, W. B. (1966). Fishes of the Atlantic Coast of Canada. Bull. Fish. Res. Bd Can. 155: 1-485

Lloyd, M. (1967). Mean crowding. J. Anim. Ecol. 36: 1-30

MacArthur, R. H. (1969). Patterns of communities in the tropics. Biol. J. Linnean Soc. Lond. 1: 19-30

Mackas, D. L. (1984). Spatial autocorrelation of plankton community composition in a continental shelf ecosystem. Limnol. Oceanogr. 29: 451-471

Mackas, D. L., Boyd, C. M. (1979). Spectral analysis of zooplankton spatial heterogeneity. Science 204:62-64

Matern, B. (1960). Spatial variation. Stochastic models and their application to some problems in forest surveys and other sampling investigations. Medd. Statens Skogsforskningsinst. Swed. 49: 1-144

Mobil Oil Canada, Ltd (1985). Hibernia development project environmental impact statement. Vol IIIa. Mobil Oil Canada, Ltd, St. John's

Nesis, K. I. (1965). Biocoenoses and biomass of benthos of the Newfoundland-Labrador region. Trudý VNIRO 57 : 453-489. Fish. Res. Bd Can. Translation 1375

Nittrouer, C. T. (1981). Sedimentary dynamics of continental shelves. Mar. Geol 42: 1-449

Nowell, A. R. M., Jumars, P. A. (1984). Flow environments of aquatic benthos. Ann. Rev. Ecol. Syst. 15: 303-328

Petrie, B., Anderson, C. (1983). Circulation on the Newfoundland continental shelf. Atmosphere-Ocean 21: 207-226

Pinhorn, A. T. (1976). Living marine resources of Newfoundland-Labrador status and potential. Bull. Fish Res. Bd Can. 194: 1-64

Pitt, T K. (1973). Food of the American plaice (Hippoglossoides platessoides) from the Grand Banks, Newfoundland. J. Fish Res. Bd Can. 30: 1261-1273

Pitt, T. K. (1976). Food of yellowtail flounder on the Grand Bank and a comparison with American plaice. International Commission for the Northwest Atlantic Fisheries (ICNAF) Res. Bull. 12: 23-27

Platt, T. (1972). Local phytoplankton abundance and turbulence. Deep Sea Res. 19: 183-187

Platt, T., Denman, K. L. (1975). Spectral analysis in ecology Ann. Rev. Ecol. Syst. 6: 189-210

Reed, W. J. (1983). Confidence estimation of ecological aggregation indices based on counts - a robust procedure. Biometrics 39: 987-998

Rhoads, D. (1970). Mass properties, stability and ecology of marine muds related to burrowing activity. In: Crimes, T P., Harper, J. C. (ed.) Trace fossils. Geol. J. Spec. Issue 3: 391-406

Ripley, B. D. (1978). Spectral analysis and the analysis of pattern in plant communities. J. Ecol. 66: 965-981

Ripley, B. D. (1981). Spatial statistics. John Wiley, New York

Sanders, H. (1960). Benthic studies in Buzzard's Bay. III. The structure of the soft-bottom community. Limnol. Oceanogr. 5: $138-153$

Sokal, R. R., Rohlf, F. J. (1981). Biometry, Freeman, San Francisco

Star, J. L., Mullin, M. M. (1981). Zooplankton assemblages in three areas of the North Pacific as revealed by continuous horizontal transects. Deep Sea Res. 28: 1303-1322

Steele, D. H., Green, J. M., Carter, J. (1979). A biological and 
oceanographic study of the Atlantic southeast coast marine region. Parks Canada Department of Indian and Northern affairs, Ottawa

Stride, A. H. (ed.). (1982). Offshore tidal sands. Chapman and Hall, London

Upton, G., Fingleton, B. (1985). Spatial data analysis by example. Vol. I. John Wiley, New York

Ursin, E. (1960). A quantitative investigation of the echinoderm fauna of the central North Sea. Meddr. Danm. Fisk.-og Havunders., N. S. 24: 1-202
Vilks, G. (1984). Report of Cruise 83033, Bedford Institute of Oceanography, Atlantic Geosciences Centre. Geological Survey of Canada internal report, Dartmouth, Nova Scotia

Warwick, R. M., Uncles, R. J. (1980). Distribution of benthic macrofauna associations in the Bristol Channel in relation to tidal stress. Mar Ecol. Prog. Ser. 3: 97-103

Zenkevitch, L. (1963). Biology of the seas of the USSR. Allen and Unwin, London

This article was presented by Dr R. M. Warwick; it was accepted for printing on April 3, 1987 